\title{
Aeromonas simiae sp. nov., isolated from monkey faeces
}

\author{
Correspondence \\ Colette Harf-Monteil \\ colette.harf-monteil@medecine. \\ u-strasbg.fr
}

\author{
Colette Harf-Monteil, ${ }^{1}$ Anne Le Flèche, ${ }^{2}$ Philippe Riegel, ${ }^{1}$ Gilles Prévost, \\ Delphine Bermond, ${ }^{1}$ Patrick A. D. Grimont ${ }^{2}$ and Henri Monteil ${ }^{1}$ \\ 'Institute of Bacteriology UPRES-EA 3432, Louis Pasteur University, Strasbourg University \\ Hospital, 3 rue Koeberlé, F-67000 Strasbourg, France \\ ${ }^{2}$ Unité de Biodiversité des Bactéries Pathogènes Emergentes, U389 INSERM, Institut Pasteur, \\ 28 rue du Docteur Roux, F-75724 Paris, France
}

Two Aeromonas strains, IBS S6874 ${ }^{\top}$ and IBS S6652, were isolated from the faeces of two healthy monkeys (Macaca fascicularis) from Mauritius that were kept in quarantine in the Centre for Primatology, Strasbourg, France. Phylogenetic analysis based on 16S rRNA gene sequences showed that the two isolates formed an unknown genetic lineage within the genus Aeromonas. The two isolates had nearly identical sequences $(0 \cdot 1 \%$ nucleotide substitution) that were related closely to those of recognized Aeromonas species (1.7-3.5\% nucleotide substitution). DNA-DNA hybridization showed that strains IBS S6874 ${ }^{\top}$ and IBS $S 6652$ had high DNA-DNA similarity $(89 \%)$ to each other and a low level of DNA-DNA similarity to closely related taxa (18\% relatedness to Aeromonas trota and $16 \%$ relatedness to Aeromonas schubertii). Phenotypically, the two monkey isolates differed from most previously described mesophilic Aeromonas species by their lack of haemolysis on sheep-blood agar and inability to produce indole, gas from glucose or acid from mannitol. They differed from the most closely related species, A. schubertii, by their ability to produce acid from D-cellobiose and D-sucrose and by their pyrazinamidase activity. The name Aeromonas simiae sp. nov. is proposed for these isolates; strain IBS S6874 ${ }^{\top}\left(=\right.$ CIP $107798^{\top}=$ CCUG $\left.47378^{\top}\right)$ is the type strain.
The taxonomy of the genus Aeromonas has undergone continual change, due to reclassification or extended description of existing species and addition of newly described taxa (Huys et al., 1997a, 2002; Pidiyar et al., 2002; Esteve et al., 2003).

Members of the genus Aeromonas are widespread in environmental habitats, such as soil (Brandi et al., 1996), fresh and brackish water, sewage and wastewater (Holmes et al., 1996). They are implicated as pathogens of coldblooded animals and various mammals, including humans, where they cause severe gastroenteritis, soft-tissue infections and bacteraemia (Janda \& Abbott, 1998). Aeromonas isolates have been recovered from faeces in acute cases of gastroenteritis, as well as in asymptomatic cases (Hänninen \& Siitonen, 1995). During a routine survey to determine the presence of possible pathogens in the intestinal tract

Published online ahead of print on 3 October 2003 as DOI 10.1099/ ijs.0.02786-0.

Abbreviations: CCUG, Culture Collection, University of Göteborg; CIP, Collection de l'Institut Pasteur.

The GenBank/EMBL/DDBJ accession number for the 16S rRNA gene sequence of strain IBS S6874 $4^{\top}$ is AJ536821. of monkeys (Macaca fascicularis) from Mauritius that had been put in quarantine in the Centre for Primatology, Louis Pasteur University, Strasbourg, France, two phenotypically related strains, which were identified tentatively as Aeromonas sp., were isolated. These strains could not be identified as members of any previously described Aeromonas species. In the current investigation, phylogenetic analysis of $16 \mathrm{~S}$ rRNA gene sequences, DNA-DNA hybridization and extensive phenotypic tests were undertaken to determine the taxonomic position of the two monkey isolates. Based on the reported data, we describe a novel species of the genus Aeromonas, for which the name Aeromonas simiae sp. nov. is proposed.

Two strains (Institute of Bacteriology of Strasbourg strain IBS S6874 ${ }^{\mathrm{T}}=\mathrm{CIP} 107798^{\mathrm{T}}=\mathrm{CCUG} 47378^{\mathrm{T}}$ and IBS S6652 = CIP 107797) were each isolated from a different sample of faeces from two healthy monkeys ( $M$. fascicularis) from Mauritius that were kept in quarantine in the Centre for Primatology, Louis Pasteur University, Strasbourg, France, and were sampled routinely in September 1999. Reference strains of other Aeromonas species were obtained from the Collection de l'Institut Pasteur (CIP), Paris, France.

Strains were cultivated aerobically on sheep-blood agar 
[trypticase soy agar (bioMérieux) that was supplemented with $5 \%$ defibrinated sheep blood] and on Mueller-Hinton agar (Bio-Rad) plates at $30^{\circ} \mathrm{C}$ unless indicated otherwise.

Cell shape, Gram-stain and biochemical activities were determined with cultures grown overnight on MuellerHinton medium (Smibert \& Krieg, 1981). Kovacs cytochrome oxidase was tested by using commercially available discs that were impregnated with dimethylparaphenylene diamine oxalate (Bio-Rad). D-Glucose fermentation by the method of Hugh \& Leifson (1953), salt tolerance and resistance to vibriostatic agent $\mathrm{O} / 129(150 \mu \mathrm{g})$ were determined by methods described by Lee \& Donovan (1985). Staining of flagella was performed according to the Rhodes method (Buttiaux et al., 1966).

Together with three reference strains of Aeromonas (Aeromonas veronii CIP $103438^{\mathrm{T}}$, Aeromonas schubertii CIP $103437^{\mathrm{T}}$ and Aeromonas caviae CIP $76.16^{\mathrm{T}}$ ), they were tested for physiological and biochemical properties according to the identification scheme described by Abbott et al. (1992). The following biochemical tests were performed by using previously described methods and incubation was carried out at $30{ }^{\circ} \mathrm{C}$ for $48 \mathrm{~h}$ : indole production by using peptone water $[1 \%(\mathrm{w} / \mathrm{v})$ peptone supplemented with $0.5 \%$ tryptophan] (Smibert \& Krieg, 1981); gas production from D-glucose (Lee et al., 1981); lysine and ornithine decarboxylase and arginine dihydrolase activities were determined in Fay-Barry medium as described by Altwegg et al. (1987). Acetoin production (Voges-Proskauer test) and aesculin hydrolysis were performed as described by Lee \& Donovan (1985). Fermentation of carbohydrates (acid production) was determined in nutrient broth (Difco) that was supplemented with $0.002 \%$ phenol red and one of the following substrates: lactose, D-mannitol, sucrose, L-arabinose, salicin or D-cellobiose. Yellow colour of the liquid medium was considered to be a positive reaction. Haemolysis of sheep blood was determined on trypticase soy agar supplemented wih $5 \%$ defibrinated sheep blood. Pyrazinamidase activity was determined by using pyrazinamidase diagnostic tablets (Eurobio Rosco) according to the manufacurer's instructions. For additional biochemical tests, API $50 \mathrm{CH}$ strips (bioMérieux) were used according to the manufacturer's instructions. Growth at 37 and $42{ }^{\circ} \mathrm{C}$ was tested in nutrient broth (Difco); cultures were incubated for $24 \mathrm{~h}$. Susceptibility to cephalothin and ampicillin was tested by the BauerKirby disc diffusion method (Bauer et al., 1966).

For small-subunit rDNA sequencing and phylogenetic study, strains were cultured on Columbia agar (Difco) at $37^{\circ} \mathrm{C}$. DNA was extracted and purified with an IsoQuick Nucleic Acid Extraction kit (ORCA Research). Using universal primers, $1.5 \mathrm{~kb}$ of the $16 \mathrm{~S}$ rRNA gene was amplified by PCR: the primers used were A, corresponding to positions 8-28 of the Escherichia coli 16S rRNA gene (Edwards et al., 1989), and rJ, complementary to positions 1510-1492 (Janvier \& Grimont, 1995).

The amplification reaction was carried out in a final volume of $100 \mu$ l, with $1 \mu$ template, $20 \mathrm{pmol}$ each primer $\mathrm{ml}^{-1}$, $200 \mu \mathrm{M}$ each dNTP, $50 \mu \mathrm{M} \mathrm{MgCl}_{2}, 2 \cdot 5 \mathrm{U}$ Taq polymerase and $10 \mu \mathrm{l} 10 \times$ reaction buffer (Amersham Biosciences). Initial denaturation was carried out for $4 \mathrm{~min}$ at $94^{\circ} \mathrm{C}$. Amplification (35 cycles) was performed in a DNA Thermal Cycler 9700 (PE Applied Biosystems). Each cycle consisted of three steps: denaturation at $94^{\circ} \mathrm{C}$ for $1 \mathrm{~min}$, annealing at $49^{\circ} \mathrm{C}$ for $1 \mathrm{~min}$ and extension at $72^{\circ} \mathrm{C}$ for $2 \mathrm{~min}$. A final extension was performed at $72{ }^{\circ} \mathrm{C}$ for 5 min.

PCR products were detected by electrophoresis on $0 \cdot 8 \%$ agarose gels in Tris/borate/EDTA buffer (0.089 M Tris/ borate, $0.018 \mathrm{M}$ EDTA) with $1 \mathrm{~kb}$ DNA ladder (Gibco$\mathrm{BRL})$ as the molecular size marker.

The amplified product was sequenced by Genome Express (Meylan, France) with three primers, E, $\mathrm{rE}$ and D, which are located in conserved regions of the E. coli $16 \mathrm{~S}$ rRNA gene. Primer E corresponded to positions 787-806, primer $\mathrm{rE}$ was complementary to primer $\mathrm{E}$ and primer $\mathrm{D}$ corresponded to positions 519-536 [numbering according to Brosius et al. (1978)].

Sequences of strains IBS S6874 ${ }^{\mathrm{T}}$ (GenBank accession no. AJ536821) and IBS S6652 (AJ536820) were compared and aligned with those of other strains, which were obtained from GenBank (http://www.ncbi.nlm.nih.gov/) by using BLAST (NCBI) and the MegAlign module of the Lasergene software (DNASTAR). A phylogenetic tree was generated by using the neighbour-joining algorithm (Saitou \& Nei, 1987).

DNA-DNA hydridization was performed as described previously (Riegel et al., 1994). Briefly, DNA was extracted from SDS-treated cells of strains IBS S6874 ${ }^{\mathrm{T}}$, IBS S6652, A. schubertii CIP $103437^{\mathrm{T}}$ and Aeromonas trota CIP $103677^{\mathrm{T}}$ by using a phenol/chloroform-based procedure. DNA was quantified spectrophotometrically and the purity of each preparation was ascertained by measuring the $A_{280} / A_{260}$ and $A_{230} / A_{260}$ ratios. Hybridization between labelled DNA and the fragmented DNA preparation was carried out at $60{ }^{\circ} \mathrm{C}$ for $16 \mathrm{~h}$ in $0.42 \mathrm{M} \mathrm{NaCl}$ by the nuclease/trichloroacetic acid method (Grimont et al., 1980). Values of DNADNA relatedness that are given are means of the results of three independent experiments.

Isolates IBS $56874^{\mathrm{T}}$ and IBS S6652, which are studied herein, were recovered on blood agar plates from different faeces samples from two healthy monkeys. These two isolates were identified as members of the genus Aeromonas, as they were Gram-negative rods with polar flagella that were oxidase-positive, glucose-fermenting, facultatively anaerobic, unable to grow in nutrient broth with $6 \%$ $\mathrm{NaCl}$ and resistant to vibriostatic agent $\mathrm{O} / 129(150 \mu \mathrm{g})$. The biochemical patterns of these two strains were nearly identical and did not permit their assignment to any recognized Aeromonas species. In addition, there was $89 \%$ DNA-DNA hybridization between isolates IBS $56874^{\mathrm{T}}$ and IBS S6652, indicating that these two strains should be assigned to the same genomospecies. 
In order to determine the taxonomic position of these two strains, which differ from recognized Aeromonas species, we studied them and reference strains by performing DNA-DNA hybridization analysis and small-subunit rDNA sequence analysis. The almost-complete sequence of strain IBS S6874 ${ }^{\mathrm{T}}$ (1452 bp), and a large part of the sequence of strain IBS S6652 (1239 bp), were determined. Phylogenetic analyses confirmed that the two strains belonged to the robust monophyletic unit that groups all available Aeromonas sequences together (Fig. 1). Comparison of $16 \mathrm{~S}$ rDNA sequences revealed that those from the two strains exhibited a high level of similarity to each other $(0 \cdot 1 \%$ nucleotide substitution), but that they represented an unknown phylogenetic lineage within the genus Aeromonas. The lowest level of nucleotide substitution between strain IBS $S 6874^{\mathrm{T}}$ and a currently recognized Aeromonas species was $1.7 \%$ (A. schubertii); nucleotide substitution with other representatives of the genus Aeromonas (listed in Fig. 1) ranged from $2 \cdot 0$ to $3 \cdot 5 \%$. It is noteworthy that these values are above the nucleotide substitution values that are usually obtained between recognized species of the genus Aeromonas (MartínezMurcia et al., 1992a, b; Pidiyar et al., 2002). According to the limitations of $16 \mathrm{~S}$ rDNA analysis in the determination of novel taxa (Martínez-Murcia, 1999), DNA-DNA hybridization was performed between strain IBS S6874 and reference strains A. trota CIP $103677^{\mathrm{T}}$ and $A$. schubertii CIP $103437^{\mathrm{T}}$, yielding values of 18 and $16 \%$, respectively. Thus, DNA-DNA hybridization clearly segregated strain IBS $56874^{\mathrm{T}}$ from A. trota and A. schubertii, which were closely related taxa on the basis of $16 \mathrm{~S}$ rDNA sequence comparison analysis. Therefore, according to the level of phylogenetic diversity within the genus Aeromonas and following the criteria proposed by Wayne et al. (1987) and Stackebrandt \& Goebel (1994), our 16S rDNA sequence and DNA-DNA hybridization data clearly show that the two monkey isolates form a novel genomic species within the genus Aeromonas.

Similar results were obtained by classical methods of carbohydrate fermentation determined on nutrient broth and by API $50 \mathrm{CH}$ strips (data not shown). Table 1 shows selected biochemical characters for phenotypic differentiation from other Aeromonas species. Thus, the two isolates differ from most previously described mesophilic Aeromonas species, except for $A$. schubertii, by their inability to produce indole, gas from glucose and acid from D-mannitol. The monkey isolates differ from A. schubertii by their ability to produce acid from D-cellobiose and D-sucrose and by their pyrazinamidase activity. The two isolates could be

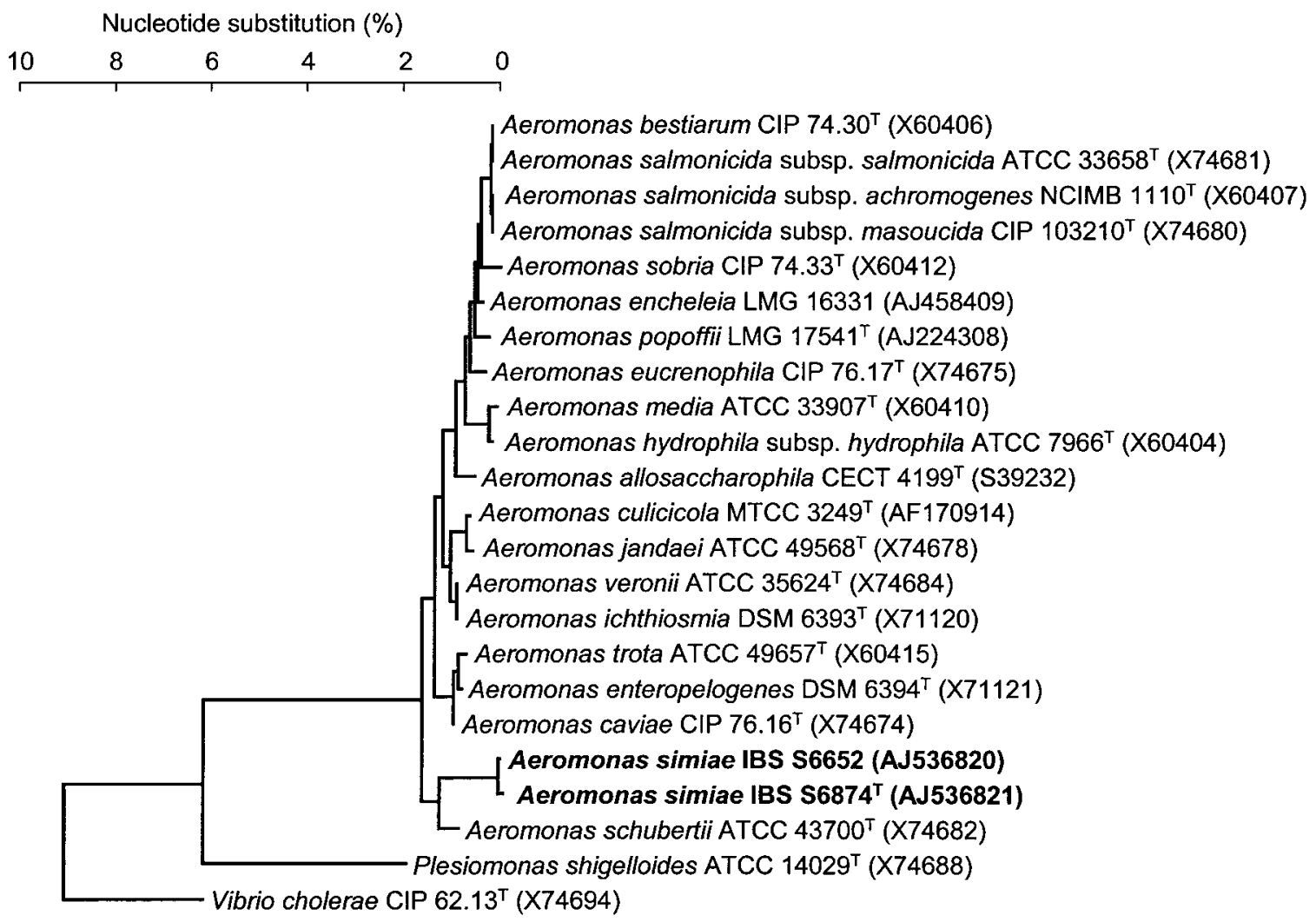

Fig. 1. Phylogenetic tree of $16 \mathrm{~S}$ rRNA gene sequences of strains IBS S6874 ${ }^{\top}$, IBS S6652, representative Aeromonas species and some relatives, constructed by using the neighbour-joining method (Saitou \& Nei, 1987). GenBank accession numbers are given in parentheses. 
Table 1. Key tests for phenotypic differentiation of Aeromonas simiae from other Aeromonas species

Taxa are identified as: 1, A. simiae sp. nov.; 2, Aeromonas hydrophila; 3, A. hydrophila subsp. dhakensis; 4, Aeromonas bestiarum; 5, A. caviae; 6, Aeromonas media; 7, Aeromonas eucrenophila; 8, Aeromonas sobria; 9, A. veronii biogroup sobria; 10, Aeromonas culicicola; 11, A. veronii biogroup veronii; 12, Aeromonas jandaei; 13, Aeromonas encheleia; 14, A. schubertii; 15, A. trota; 16, Aeromonas allosaccharophila; 17, Aeromonas popoffii. Data were taken from Abbott et al. (1992, 2003), Martínez-Murcia et al. (1992b), Esteve et al. (1995, 2003), Ali et al. (1996), Huys et al. (1997b, 2002), Altwegg (1999) and Pidiyar et al. (2002). Characters are scored as: +, >85\% of positive strains; ,$-<15 \%$ of positive strains; $\mathrm{V}+, 60-85 \%$ of positive strains; $\mathrm{V}-, 15-40 \%$ of positive strains; $\mathrm{V}$, around $50 \%$ of positive strains; ND, no data from these authors.

\begin{tabular}{|c|c|c|c|c|c|c|c|c|c|c|c|c|c|c|c|c|c|}
\hline Character & 1 & 2 & 3 & 4 & 5 & 6 & 7 & 8 & 9 & 10 & 11 & 12 & 13 & 14 & 15 & 16 & 17 \\
\hline Production of gas from glucose & - & + & ND & $\mathrm{v}+$ & - & - & + & $\mathrm{V}$ & + & + & $\mathrm{v}+$ & + & $\mathrm{v}+$ & - & $\mathrm{v}+$ & + & + \\
\hline Hydrolysis of aesculin & $\mathrm{V}$ & + & + & + & + & + & + & - & - & $\mathrm{ND}$ & + & - & + & - & - & $\mathrm{v}+$ & - \\
\hline Indole production & - & + & + & + & + & + & + & + & + & + & + & + & + & - & + & + & $\mathrm{v}+$ \\
\hline \multicolumn{18}{|l|}{ Acid from: } \\
\hline Salicin & - & + & + & $\mathrm{v}+$ & + & $\mathrm{V}-$ & + & - & - & - & + & - & + & - & - & - & - \\
\hline D-Cellobiose & + & - & - & - & + & + & + & + & $\mathrm{v}+$ & - & $v+$ & - & - & - & + & + & - \\
\hline D-Mannitol & - & + & + & + & + & + & + & + & + & + & + & + & + & - & $\mathrm{v}+$ & + & + \\
\hline D-Sucrose & + & + & + & + & + & + & $\mathrm{v}+$ & + & + & + & + & $\mathrm{v}+$ & $\mathrm{v}+$ & - & $\mathrm{v}-$ & + & - \\
\hline L-Arabinose & - & + & - & + & + & + & $\mathrm{v}+$ & - & $\mathrm{V}-$ & - & - & - & - & - & - & $\mathrm{V}+$ & $\mathrm{v}$ \\
\hline \multicolumn{18}{|l|}{ Decarboxylation of: } \\
\hline Ornithine & - & - & - & - & - & - & - & - & - & - & + & - & - & - & - & $\mathrm{v}-$ & - \\
\hline Lysine & + & + & + & + & - & - & - & + & + & + & + & + & - & $\mathrm{v}+$ & + & + & - \\
\hline Arginine dihydrolase & + & + & + & + & + & + & + & - & + & + & - & + & + & + & + & $\mathrm{v}+$ & + \\
\hline Pyrazinamidase activity & + & + & ND & $\mathrm{V}+$ & $\mathrm{v}+$ & $\mathrm{V}-$ & + & - & - & ND & - & - & - & - & - & $\mathrm{V}-$ & - \\
\hline
\end{tabular}

differentiated from one another by some phenotypic features: according to the data obtained by using API $50 \mathrm{CH}$ strips, strain IBS $\mathrm{S} 6874^{\mathrm{T}}$ produced acid from arbutin, but did not hydrolyse aesculin after $48 \mathrm{~h}$ incubation, in contrast to strain IBS S6652.

As strains IBS $\mathrm{S} 6874^{\mathrm{T}}$ and IBS $\mathrm{S} 6652$ constitute a distinct genomic species that can be identified by phenotypic properties, they represent a novel species, for which the name Aeromonas simiae sp. nov. is proposed.

\section{Description of Aeromonas simiae sp. nov.}

Aeromonas simiae (si'mi.ae. Gr. n. simia monkey; N.L. adj. simiae from monkeys).

Strains display the following characteristics that are typical of the genus Aeromonas: Gram-negative, straight, motile rods with a polar flagellum, cytochrome oxidase-positive, chemoorganotrophic with both oxidative and fermentative metabolisms, catalase-positive, reduce nitrate to nitrite without production of gas and resistant to vibriostatic agent $\mathrm{O} / 129(150 \mu \mathrm{g})$. Unable to grow in nutrient broth with $6 \% \mathrm{NaCl}$. Optimal growth occurs at $30{ }^{\circ} \mathrm{C}$ after $24 \mathrm{~h}$ on trypticase soy agar or sheep-blood agar, but strains also grow at $42{ }^{\circ} \mathrm{C}$ after $24 \mathrm{~h}$. Unable to produce indole, gas from glucose or $\beta$-haemolysis on sheep-blood agar. VogesProskauer- and ornithine decarboxylase-negative; lysine decarboxylase-, arginine dihydrolase- and pyrazinamidasepositive. Hydrolysis of aesculin and acid production from arbutin are variable. By fermentation, acid is produced from glycerol, ribose, galactose, D-glucose, D-fructose, D-mannose, $\mathrm{N}$-acetylglucosamine, D-cellobiose, D-sucrose, D-maltose, D-trehalose, starch, glycogen and gluconate, but not from erythritol, D-arabinose, L-arabinose, D-xylose, L-xylose, adonitol, methyl $\beta$-D-xyloside, sorbose, rhamnose, dulcitol, inositol, mannitol, sorbitol, methyl $\alpha$-D-mannoside, methyl $\alpha$-D-glucoside, amygdalin, melibiose, inulin, melezitose, raffinose, xylitol, gentiobiose, turanose, D-lyxose, D-tagatose, D-fucose, D-arabitol, 2-ketogluconate, 5-ketogluconate, salicin or lactose. Major characteristics that differentiate the species from other Aeromonas species are shown in Table 1. Susceptible to cephalothin, but resistant to ampicillin.

The type strain, IBS $66874^{\mathrm{T}}\left(=\mathrm{CIP} 107798^{\mathrm{T}}=\mathrm{CCUG}\right.$ $\left.47378^{\mathrm{T}}\right)$, was isolated from the faeces of a monkey (Macaca fascicularis) that was kept in the Centre for Primatology, Louis Pasteur University, Strasbourg, France. This strain has all of the above-described properties for the species; in addition, aesculin is not hydrolysed after $48 \mathrm{~h}$ incubation and acid is produced from arbutin.

\section{Acknowledgements}

We are grateful to Béatrice Muller, Institute of Bacteriology, Strasbourg, France, for her technical assistance. We also wish to thank J. P. Euzéby, École Nationale Vétérinaire, Toulouse, France, for advice concerning the Latin species name and Nicolas Herrenschmidt, Centre for Primatology, Louis Pasteur University, Strasbourg, France, for providing monkey faeces. This research was supported by project grant UPRES-EA 3432, 2001-2004, from the Ministère de l'Education Nationale et de l'Enseignement Supérieur, Paris, France. 


\section{References}

Abbott, S. L., Cheung, W. K. W., Kroske-Bystrom, S., Malekzadeh, T. \& Janda, J. M. (1992). Identification of Aeromonas strains to the genospecies level in the clinical laboratory. J Clin Microbiol 30, 1262-1266.

Abbott, S. L., Cheung, W. K. W. \& Janda, J. M. (2003). The genus Aeromonas: biochemical characteristics, atypical reactions, and phenotypic identification schemes. J Clin Microbiol 41, 2348-2357.

Ali, A., Carnahan, A. M., Altwegg, M., Lüthy-Hottenstein, J. \& Joseph, S. W. (1996). Aeromonas bestiarum sp. nov. (formerly genomospecies DNA group $2 \mathrm{~A}$. hydrophila), a new species isolated from non-human sources. Med Microbiol Lett 5, 156-165.

Altwegg, M. (1999). Aeromonas and Plesiomonas. In Manual of Clinical Microbiology, 7th edn, pp. 507-516. Edited by P. R. Murray, E. J. Baron, M. A. Pfaller, F. C. Tenover \& R. H. Yolken. Washington, DC: American Society for Microbiology.

Altwegg, M., von Graevenitz, A. \& Zollinger-Iten, J. (1987). Medium and temperature dependence of decarboxylase reactions in Aeromonas spp. Curr Microbiol 15, 1-4.

Bauer, A. W., Kirby, W. M. M., Sherris, J. C. \& Turck, M. (1966). Antibiotic susceptibility testing by a standardized single disk method. Am J Clin Pathol 45, 493-496.

Brandi, G., Sisti, M., Schiavano, G. F., Salvaggio, L. \& Albano, A. (1996). Survival of Aeromonas hydrophila, Aeromonas caviae and Aeromonas sobria in soil. J Appl Bacteriol 81, 439-444.

Brosius, J., Palmer, M. L., Kennedy, P. J. \& Noller, H. F. (1978). Complete nucleotide sequence of a $16 \mathrm{~S}$ ribosomal RNA gene from Escherichia coli. Proc Natl Acad Sci U S A 75, 4801-4805.

Buttiaux, R., Beerens, H. \& Tacquet, A. (1966). Coloration de Rhodes. In Manuel de Techniques Bactériologiques, p. 48. Paris: Editions Médicales Flammarion (in French).

Edwards, U., Rogall, T., Blöcker, H., Emde, M. \& Böttger, E. C. (1989). Isolation and direct complete nucleotide determination of entire genes. Characterization of a gene coding for $16 \mathrm{~S}$ ribosomal RNA. Nucleic Acids Res 17, 7843-7853.

Esteve, C., Gutiérrez, M. C. \& Ventosa, A. (1995). Aeromonas encheleia sp. nov., isolated from European eels. Int J Syst Bacteriol 45 , 462-466.

Esteve, C., Valera, L., Gutiérrez, C. \& Ventosa, A. (2003). Taxonomic study of sucrose-positive Aeromonas jandaei-like isolates from faeces, water and eels: emendation of A. jandaei Carnahan et al. 1992. Int J Syst Evol Microbiol 53, 1411-1419.

Grimont, P. A. D., Popoff, M. Y., Grimont, F., Coynault, C. \& Lemelin, M. (1980). Reproducibility and correlation study of three deoxyribonucleic acid hybridization procedures. Curr Microbiol 4 325-330.

Hänninen, M.-L. \& Siitonen, A. (1995). Distribution of Aeromonas phenospecies and genospecies among strains isolated from water, foods or from human clinical samples. Epidemiol Infect $\mathbf{1 1 5}$ 39-50.

Holmes, P., Niccolls, L. M. \& Sartory, D. P. (1996). The ecology of mesophilic Aeromonas in the aquatic environment. In The Genus Aeromonas, pp. 127-150. Edited by B. Austin, M. Altwegg, P. J. Gosling \& S. Joseph. Chichester, UK: Wiley.

Hugh, R. \& Leifson, E. (1953). The taxonomic significance of fermentative versus oxidative metabolism of carbohydrates by various gram-negative bacteria. J Bacteriol 66, 24-26.
Huys, G., Kämpfer, P., Altwegg, M., Coopman, R., Janssen, P., Gillis, M. \& Kersters, K. (1997a). Inclusion of Aeromonas DNA hybridization group 11 in Aeromonas encheleia and extended descriptions of the species Aeromonas eucrenophila and A. encheleia. Int J Syst Bacteriol 47, 1157-1164.

Huys, G., Kämpfer, P., Altwegg, M. \& 7 other authors (1997b). Aeromonas popoffii sp. nov., a mesophilic bacterium isolated from drinking water production plants and reservoirs. Int J Syst Bacteriol 47, 1165-1171.

Huys, G., Kämpfer, P., Albert, M. J., Kühn, I., Denys, R. \& Swings, J. (2002). Aeromonas hydrophila subsp. dhakensis subsp. nov., isolated from children with diarrhoea in Bangladesh, and extended description of Aeromonas hydrophila subsp. hydrophila (Chester 1901) Stanier 1943 (Approved Lists 1980). Int J Syst Evol Microbiol 52, 705-712. Janda, J. M. \& Abbott, S. L. (1998). Evolving concepts regarding the genus Aeromonas: an expanding panorama of species, disease presentations, and unanswered questions. Clin Infect Dis 27, 332-344.

Janvier, M. \& Grimont, P. A. D. (1995). The genus Methylophaga, a new line of descent within phylogenetic branch $\gamma$ of proteobacteria. Res Microbiol 146, 543-550.

Lee, J. V. \& Donovan, T. J. (1985). Vibrio, Aeromonas and Plesiomonas. Soc Appl Bacteriol Tech Ser 21, 13-33.

Lee, J. V., Shread, P., Furniss, A. L. \& Bryant, T. N. (1981). Taxonomy and description of Vibrio fluvialis sp. nov. (synonym group F vibrios, group EF6). J Appl Bacteriol 50, 73-95.

Martínez-Murcia, A. J. (1999). Phylogenetic positions of Aeromonas encheleia, Aeromonas popoffi, Aeromonas DNA hybridization Group 11 and Aeromonas Group 501. Int J Syst Bacteriol 49, 1403-1408.

Martínez-Murcia, A. J., Benlloch, S. \& Collins, M. D. (1992a). Phylogenetic interrelationships of members of the genera Aeromonas and Plesiomonas as determined by $16 \mathrm{~S}$ ribosomal DNA sequencing: lack of congruence with results of DNA-DNA hybridizations. Int $J$ Syst Bacteriol 42, 412-421.

Martínez-Murcia, A. J., Esteve, C., Garay, E. \& Collins, M. D. (1992b). Aeromonas allosaccharophila sp. nov., a new mesophilic member of the genus Aeromonas. FEMS Microbiol Lett 91, 199-206.

Pidiyar, V., Kaznowski, A., Narayan, N. B., Patole, M. \& Shouche, Y. S. (2002). Aeromonas culicicola sp. nov., from the midgut of Culex quinquefasciatus. Int J Syst Evol Microbiol 52, 1723-1728.

Riegel, P., de Briel, D., Prévost, G., Jehl, F. \& Monteil, H. (1994). Genomic diversity among Corynebacterium jeikeium strains and comparison with biochemical characteristics and antimicrobial susceptibilities. J Clin Microbiol 32, 1860-1865.

Saitou, N. \& Nei, M. (1987). The neighbor-joining method: a new method for reconstructing phylogenetic trees. Mol Biol Evol 4, 406-425.

Smibert, R. M. \& Krieg, N. R. (1981). General characterization. In Manual of Methods for General Microbiology, pp. 409-443. Edited by P. Gerhardt, R. G. E. Murray, R. N. Costilow, E. W. Nester, W. A. Wood, N. R. Krieg \& G. B. Phillips. Washington, DC: American Society for Microbiology.

Stackebrandt, E. \& Goebel, B. M. (1994). Taxonomic note: a place for DNA-DNA reassociation and 16S rRNA sequence analysis in the present species definition in bacteriology. Int J Syst Bacteriol 44, 846-849.

Wayne, L. G., Brenner, D. J., Colwell, R. R. \& 9 other authors (1987). International Committee on Systematic Bacteriology. Report of the ad hoc committee on reconciliation of approaches to bacterial systematics. Int J Syst Bacteriol 37, 463-464. 